\section{Regards sur l'économie allemande}

Bulletin économique du CIRAC

$97 \mid 2010$

Varia

\title{
Elites économiques
}

FREYE Saskia, Führungswechsel. Die Wirtschaftselite und das Ende der Deutschland AG

\section{(2) OpenEdition}

\section{Journals}

Édition électronique

URL : http://journals.openedition.org/rea/4160

DOI : $10.4000 /$ rea. 4160

ISBN : 978-2-8218-0890-4

ISSN : 1965-0787

Éditeur

CIRAC

\section{Édition imprimée}

Date de publication : 1 juillet 2010

Pagination : 36

ISSN : 1156-8992

Référence électronique

"Elites économiques », Regards sur l'économie allemande [En ligne], 97 | juillet 2010, mis en ligne le 13 juillet 2010, consulté le 22 septembre 2020. URL : http://journals.openedition.org/rea/4160; DOI : https://doi.org/10.4000/rea.4160

Ce document a été généré automatiquement le 22 septembre 2020

(c) CIRAC 


\section{Elites économiques}

FREYE Saskia, Führungswechsel. Die Wirtschaftselite und das Ende der Deutschland AG

\section{RÉFÉRENCE}

FREYE Saskia, Führungswechsel. Die Wirtschaftselite und das Ende der

Deutschland AG, Schriften aus dem Max-Planck-Institut für Gesellschaftsforschung, Campus Verlag, Francfort/New York, 2010, 228 p.

1 Cette analyse de l'évolution des élites économiques allemandes sur plus de 4 décennies montre que les biographies des grands dirigeants de l'industrie ont profondément changé depuis la fin des années 1980, parallèlement aux mutations du capitalisme rhénan. La logique de l'optimisation des profits à court terme met à mal l'orientation produit si typique du management industriel allemand. (ib) 